\title{
Metabolism of Biphenyl
}

\section{2-HYDROXY-6-OXO-6-PHENYLHEXA-2,4-DIENOATE: THE META-CLEAVAGE PRODUCT FROM 2,3-DIHYDROXYBIPHENYL BY PSEUDOMONAS PUTIDA}

\author{
By DANILO CATELANI, ANTONIO COLOMBI, CLAUDIA SORLINI \\ and VITTORIO TRECCANI \\ Institute of Agrarian and Technical Microbiology, University of Milan, 20133 Milan, Italy
}

(Received 15 February 1973)

\begin{abstract}
1. 2-Hydroxy-6-oxo-6-phenylhexa-2,4-dienoic acid was isolated and identified from washed suspensions of Pseudomonas putida incubated in the presence of 2,3-dihydroxybiphenyl. 2. Benzoic acid was isolated from reaction mixtures of crude cell-free extracts incubated with 2,3-dihydroxybiphenyl. 3. The presence in the same reaction mixtures of either 4-hydroxy-2-oxovalerate or 2-hydroxypenta-2,4-dienoate was suggested by mass spectrometry. 4 . The degradative pathway of biphenyl is discussed.
\end{abstract}

During a study on the microbial decontamination of waste waters containing aromatic hydrocarbons used as nuclear reactor coolants, Catelani et al. (1970) isolated by enrichment culture a strain of Pseudomonas putida able to grow on biphenyl supplied as the sole carbon and energy source. Lunt \& Evans (1970) isolated a Gram-negative bacterium able to metabolize biphenyl with the formation of 2,3-dihydroxybiphenyl, $\alpha$-hydroxy- $\beta$-phenylmuconic semialdehyde and phenylpyruvic acid. Catelani et al. (1971) showed that cultures of Ps. putida grown on biphenyl yielded both 2,3-dihydro-2,3-dihydroxybiphenyl and benzoic acid; moreover the same cells grown on biphenyl were simultaneously induced to oxidize biphenyl and benzoic acid but not 3,4-dihydroxybiphenyl and phenylpyruvic acid; only the cells grown on phenylpyruvic acid were simultaneously induced to exidize this compound.

In the present paper the metabolic pathway of 2,3dihydroxybiphenyl in $P_{S}$. putida leading to the formation of benzoic acid is described.

\section{Materials and Methods}

\section{Organism and growth conditions}

A strain of Ps. putida, isolated by Catelani $e t$ al. (1970), wạs used. For maintenance, manometric experiments and preparations of cell-free extracts, the arganism was cultured on Tausson (1927) mineral salts medium, solidified with $1.8 \%$ (w/v) Difco agar (Difco Laboratories, Detroit, Mich., U.S.A.) and supplemented with crystals of biphenyl (Merck A.-G., Darmstadt, Germany) placed in the lid of inverted plates. Approx. $10 \mathrm{~g}$ (wet wt.) of cells were haryested from 50 plates of $15 \mathrm{~cm}$ diam. after $24 \mathrm{~h}$ incubation, and washed twice by centrifugation in $0.02 \mathrm{M}$-potassium phosphate buffer, pH7. For manometric experiments the cells were resuspended in the same potas- sium phosphate buffer to give a total $\mathrm{N}$ content of $0.3 \mathrm{mg} / \mathrm{ml}$. The measurement of $\mathrm{O}_{2}$ uptake was performed in a Warburg respirometer at $30^{\circ} \mathrm{C}$.

\section{Cell-free extracts}

Freshly harvested cells ( $10 \mathrm{~g}$ wet $\mathrm{wt}$.$) , suspended in$ $10 \mathrm{ml}$ of $0.02 \mathrm{M}$-potassium phosphate buffer, $\mathrm{pH} 7$, were crushed at $4-5^{\circ} \mathrm{C}$ in an Aminco French Pressure Cell (American Instrument Co. Inc., Washington, D.C., U.S.A.) at $1.42 \times 10^{5} \mathrm{kPa}$. The crude extract was incubated with $10 \mu \mathrm{g}$ of deoxyribonuclease (Mann Research Laboratories, New York, N.Y., U.S.A.) for $15 \mathrm{~min}$ at $0^{\circ} \mathrm{C}$ and centrifuged. The supernatant solution, which usually contained about $40 \mathrm{mg}$ of protein $/ \mathrm{ml}$, was diluted with phosphate buffer to about $20 \mathrm{mg}$ of protein $/ \mathrm{ml}$.

\section{Spectral analyses}

U.v. spectra were recorded in a Zeiss PMQII spectrophotometer; an Infracord model 137 (PerkinElmer Ltd., Beaconsfield, Bucks., U.K.) was used to obtain i.r. spectra (in Nujol). Mass spectra were recorded on an LKB model 9000 spectrometer.

\section{Chemical determinations}

The presence of a free aldehyde group was assayed by the Tollens test (Vogel, 1970). Protein was determined by the method of Warburg \& Christian (1941). Methyl esters were prepared by one of the following procedures: methanol- $\mathrm{BF}_{3}$, methanol-toluene- $p$ sulphonic acid or diazomethane in diethyl ether. Hydrogenation was performed in the standard apparatus as described by Canonica et al. (1966). The catalyst, $10 \%(w / w)$ Pd on charcoal or $5 \%(w / w)$ Pd on $\mathrm{CaCO}_{3}$, was obtained from Engelhard Minerals and Chemical Co., Newark, N.J., U.S.A. 


\section{Chromatography}

T.l.c. was done on silica-gel plates (Baker-flex IB-F no. 5002; J. T. Baker Chemical Co., Deventer, Holland), activated by heating at $110^{\circ} \mathrm{C}$ for $30 \mathrm{~min}$. The developing solvent system was acetic acidhexane-chloroform $(1: 8: 2$, by vol.); spots were revealed by a u.v. lamp (at $254 \mathrm{~nm}$ ).

G.l.c. of phenols and phenyl esters was performed by using a C. Erba model G.T. 200 gas chromatograph, with a flame-ionization detector. A stainlesssteel column $(2 \mathrm{~m} \times 2 \mathrm{~mm}$ internal diam.) packed with $10 \%$ SE30 on Chromosorb W (60-80 mesh) was used at the following temperatures: column $190^{\circ} \mathrm{C}$, injector $230^{\circ} \mathrm{C}$, detector $220^{\circ} \mathrm{C}$. The carrier gas was $\mathrm{N}_{2}(30 \mathrm{ml} / \mathrm{min})$. The flame was fed with $\mathrm{H}_{2}$ at $70.7 \mathrm{kPa}$ and air at $120 \mathrm{kPa}$. For g.l.c. of methyl esters, a stainless-steel column of the same dimensions was used, packed with $5 \%$ ethylene glycol succinate (C. Erba LAC886) on Chromosorb W (60-80 mesh) at the following temperatures: column $150^{\circ} \mathrm{C}$, injector $210^{\circ} \mathrm{C}$, detector $200^{\circ} \mathrm{C}$. The $\mathrm{N}_{2}, \mathrm{H}_{2}$ and air were supplied as described above. He was used as carrier gas $(30 \mathrm{ml} / \mathrm{min})$ when the gas chromatograph was combined with the LKB model 9000 mass spectrometer; columns and temperatures were the same as reported above.

\section{Chemical synthesis}

2,3-Dihydroxybiphenyl. o-Hydroxybiphenyl (17g) (Eastman-Kodak Co., Rochester, N.Y., U.S.A.) and $17.8 \mathrm{~g}$ of octanoyl chloride (Fluka AG, Buchs, Switzerland) were heated on a boiling-water bath for $6 \mathrm{~h}$. The reaction mixture was cooled and poured into $200 \mathrm{ml}$ of water and the resulting solution was boiled for $10 \mathrm{~min}$ to decompose the excess of acyl chloride. Three extractions $(200 \mathrm{ml}$ each) were performed with light petroleum (b.p. $40-60^{\circ} \mathrm{C}$ ). The extract was washed with $5 \%(\mathrm{w} / \mathrm{v}) \mathrm{NaHCO}_{3}$, dried over anhydrous $\mathrm{MgSO}_{4}$ and evaporated to dryness. 2-Hydroxybiphenyl octanoate $(28 \mathrm{~g})$ was obtained [b.p. $132^{\circ} \mathrm{C}$ at $6.6 \mathrm{~Pa}(0.05 \mathrm{mmHg})]$. A mixture of this compound $(24 \mathrm{~g})$ and finely powdered $\mathrm{AlCl}_{3}(20 \mathrm{~g})$ was heated on an oil bath at $160-180^{\circ} \mathrm{C}$ for $3 \mathrm{~h}$. The glassy reaction product was cooled, powdered and decomposed by gradual addition to $250 \mathrm{ml}$ of well-stirred $5 \%(\mathrm{w} / \mathrm{v}) \mathrm{HCl}$. The decomposition was completed by warming on a steam bath for a short time. The solution was cooled and three extractions were performed with $200 \mathrm{ml}$ each of diethyl ether. The dried extract was fractionated under reduced pressure. The fraction boiling at $160-170^{\circ} \mathrm{C}$ at $6.6 \mathrm{~Pa}(0.05 \mathrm{mmHg})$ was collected and redistilled. 2-Hydroxy-3-phenyloctanoylphenone was collected as a viscous liquid [b.p. $167-168^{\circ} \mathrm{C}$ at $6.6 \mathrm{~Pa}(0.05 \mathrm{mmHg})$ ]. 2,3-Dihydroxybiphenyl was obtained from 2-hydroxy-3-phenyloctanoylphenone by the Baeyer-Villiger oxidation method as modified by Dakin (1909) by using $\mathrm{H}_{2} \mathrm{O}_{2}$,
$\mathrm{KOH}$ and pyridine. The reaction mixture was extracted with diethyl ether and decolorized with charcoal. Removal of the solvent left a grey solid which was sublimed at $110^{\circ} \mathrm{C}$ at $6.6 \mathrm{~Pa}(0.05 \mathrm{mmHg})$ to give a colourless microcrystalline powder which, after crystallization from light petroleum (b.p. $80-100^{\circ} \mathrm{C}$ ), gave 2,3-dihydroxybiphenyl as colourless needles. This compound was identical (m.p. and mixed m.p. $114^{\circ} \mathrm{C}$ ) with that obtained in very low yield by the time-consuming method of Bruce \& Sutcliffe (1955).

\section{Results}

2-Hydroxy-6-oxo-6-phenylhexa-2,4-dienoate, the ringfission product of 2,3-dihydroxybiphenyl

Washed suspensions of Ps. putida grown on biphenyl rapidly oxidized 2,3-dihydroxybiphenyl with the formation of a yellow compound, showing the spectrophotometric features of $\alpha$-hydroxymuconic semialdehydes $\left(\lambda_{\max }, 390-430 \mathrm{~nm}\right.$ at $\mathrm{pH} 12$, shifting to $310-330 \mathrm{~nm}$ at $\mathrm{pH} 3$ ), which slowly disappeared in the reaction mixture. In order to isolate a sufficient amount of the yellow compound for identification $750 \mathrm{ml}$ Erlenmeyer fiasks containing $30 \mathrm{ml}$ of a washed suspension of $P$ s. putida grown on biphenyl (equivalent to a total $\mathrm{N}$ content of $0.30 \mathrm{mg} / \mathrm{ml}), 60 \mathrm{ml}$ of $0.02 \mathrm{M}$-potassium phosphate buffer, $\mathrm{pH} 7$, and $10 \mathrm{mg}$ of 2,3-dihydroxybiphenyl were incubated at $27^{\circ} \mathrm{C}$ by shaking. The yellow colour developed immediately. To check the cultures for accumulation of the yellow intermediate, $2 \mathrm{ml}$ samples were taken at intervals, made alkaline (pH12) with $1 \mathrm{M}-\mathrm{NaOH}$ and filtered. When the absorbance at $\lambda_{\max } .435 \mathrm{~nm}$ reached its maximum value, corresponding approximately to $0.45 \mathrm{mg}$ of intermediate compound $/ \mathrm{mg}$ of 2,3 -dihydroxybiphenyl, the incubation mixture from several Erlenmeyer flasks was acidified ( $\mathrm{pH} 3)$ with conc. $\mathrm{HCl}$ and cells were removed by centrifugation. The supernatant was saturated with $\mathrm{NaCl}$ and extracted five times with diethyl ether $(200 \mathrm{ml})$. The ethereal solution was cooled to $-20^{\circ} \mathrm{C}$, the ice that formed was removed and the solvent was then evaporated in the cold under reduced pressure. T.l.c. of the crude residue revealed two spots, the first one with $R_{F} \mathbf{0 . 8 5}$, identical with that of benzoic acid, and the second with $R_{F} 0.30$. The crude residue was dissolved in diethyl ether, and light petroleum (b.p. 40$60^{\circ} \mathrm{C}$ ) was slowly added with efficient stirring: the compound with $\boldsymbol{R}_{\boldsymbol{F}} \mathbf{0 . 3 0}$ was precipitated, whereas benzoic acid was almost completely soluble. The brown precipitate was recrystallized from diethyl ether-light petroleum (b.p. $40-60^{\circ} \mathrm{C}$ ). The lightbrown microcrystalline powder obtained was repeatedly washed with boiling light petroleum (b.p. $20-40^{\circ} \mathrm{C}$ ) and stored at $-20^{\circ} \mathrm{C}$ under $\mathrm{N}_{2}$. Care was taken against contamination with moisture. This 
substance (Found: $\mathrm{C}, 65.8 ; \mathrm{H}, 4.5 ; \mathrm{C}_{12} \mathrm{H}_{10} \mathrm{O}_{4}$ requires $\mathrm{C}, 66.0 ; \mathrm{H}, 4.6 \%$; uncorr. m.p. $112^{\circ} \mathrm{C}$, decomp.) was stable under these conditions and also in diluted ethereal or alkaline aqueous solutions in the cold (up to $5^{\circ} \mathrm{C}$ ). In the dry state at room temperature it was rapidly decomposed, probably by a polymerization process. The u.v. spectrum in alkaline conditions (pH 12) showed $\lambda_{\max .} 435 \mathrm{~nm}(\log \epsilon 4.5)$ and in acidic conditions ( $\mathrm{pH} 2.5) \lambda_{\max .} 336 \mathrm{~nm}(\log \epsilon 4.3)$, on account of a keto-enol tautomerism. The mass spectrum showed a molecular-ion peak at $m / e 218$ and other peaks at $m / e 173\left(M-\mathrm{CO}_{2} \mathrm{H}\right), 105\left(\mathrm{C}_{6} \mathrm{H}_{5} \mathrm{CO}^{+}\right)$ and $77\left(\mathrm{C}_{6} \mathrm{H}_{5}{ }^{+}\right)$. Peaks also appeared at $m / e 202$ and 157: in repeated recordings, these peaks showed intensities in widely varying ratios with the other reported above. The compound gave a negative Tollens test, whereas the test for enols with $\mathrm{FeCl}_{3}$ was positive. These properties are consistent with the structure of 2-hydroxy-6-oxo-6-phenylhexa-2,4-dienoic acid (compound III in Scheme 1). Methylation of this compound afforded no definite product : in fact g.l.c.-mass spectrometry gave no evidence of the presence of any methyl ester. Attempted acetylation before and/or after methylation was unsuccessful. Probably polymerization occurred in the reaction mixture producing compounds with high molecular weights and consequently low volatility.
Action of crude cell-free extracts on 2,3-dihydroxybiphenyl and 2-hydroxy-6-oxo-6-phenylhexa-2,4-dienoate

Crude cell-free extracts of Ps. putida grown on biphenyl rapidly oxidized 2,3-dihydroxybiphenyl with an $\mathrm{O}_{2}$ uptake of $1 \mathrm{~mol} / \mathrm{mol}$ of substrate, with the formation of a yellow compound that rapidly disappeared. The same cell-free extracts incubated with pure2-hydroxy-6-oxo-6-phenylhexa-2,4-dienoate, isolated as previously described, showed no $\mathrm{O}_{2}$ uptake, but the yellow colour of the reaction mixture rapidly disappeared. To isolate and identify the further dissimilation products of 2-hydroxy-6-oxo-6-phenylhexa-2,4-dienoate, $30 \mathrm{ml}$ of cell-free extract and $70 \mathrm{ml}$ of $0.02 \mathrm{M}$-potassium phosphate buffer, $\mathrm{pH} 7$, were incubated in the presence of $20 \mathrm{mg}$ of 2,3-dihydroxybiphenyl; when the yellow colour had completely disappeared the incubation mixture was acidified to pH 3 and centrifuged. The supernatant was repeatedly extracted with diethyl ether and the crude oily residue from the evaporated ethereal fraction was heated with a few $\mathrm{ml}$ of light petroleum (b.p. $30-50^{\circ} \mathrm{C}$ ), the liquid phase decanted and the solvent evaporated. White crystals were obtained after repeated crystallization from $n$-pentane (Found: C, 69.1; H, 5.0. Calc. for benzoic acid $\mathrm{C}_{7} \mathrm{H}_{6} \mathrm{O}_{2}$ : $\mathrm{C}, 68.8 ; \mathrm{H}, 4.9 \%$ ). This material was identical (m.p. and mixed m.p. $120^{\circ} \mathrm{C}$ )<smiles>[Y]C1C=CC=C(c2ccccc2)C1(O)O</smiles><smiles>Oc1cccc(-c2ccccc2)c1O</smiles><smiles>O=C(O)C(=C/C=C\C(=O)c1ccccc1)C(=O)O</smiles><smiles>C=CC=C(O)C(=O)O</smiles><smiles>CC(O)CC(=O)CC(=O)O</smiles>

Scheme 1. Proposed pathway of biphenyl degradation by Ps. putida

I, 2,3-Dihydro-2,3-dihydroxybiphenyl; II, 2,3-dihydroxybiphenyl; III, 2-hydroxy-6-oxo-6-phenylhexa-2,4dienoic acid; IV, 2-hydroxypenta-2,4-dienoic acid; V, 4-hydroxy-2-oxovaleric acid. The square brackets denote that these compounds have not been isolated and identified, but that their presence has been suggested by mass spectrometry. 
with an authentic sample of benzaic acid. The i.r., u.v. and mass spectra were wholly superimposable on those of benzoic acid. Mother liquors from the crystallization of benzoic acid were evaporated until dry. Mass spectrometry of the resulting solid residue showed that it was mainly benzoic acid; eyidence was also obtained for the presence in traces of another compound responsible for peaks at m/e 114 $\left(\mathrm{C}_{5} \mathrm{H}_{6} \mathrm{O}_{3}{ }^{+}\right), 97\left(\mathrm{C}_{5} \mathrm{H}_{5} \mathrm{O}_{2}{ }^{+}\right)$and $69\left(\mathrm{C}_{4} \mathrm{H}_{5} \mathrm{O}^{+}\right)$. These peaks are consistent with the structure of 4 -hydroxy2-oxoyaleric acid $\left[114=\left(M-\mathrm{H}_{2} \mathrm{O}\right)\right]$ or of its probable precursor 2-hydroxypenta-2,4-dienoic acid $(M=$ 114) (compounds IV and V respectively in Scheme 1).

\section{Discussion}

From washed suspensions of Ps. putida incubated with 2,3-dihydroxybiphenyl a crystalline compound was isolated whose u.v. features were similar to those of muconic semialdehydes. In addition the presence in the mass spectrum of a peak at m/e 105 indicated a partial structure $\mathrm{C}_{6} \mathrm{H}_{5} \mathrm{CO}$. These properties are consistent with the structure of 2-hydroxy-6-oxo-6phenylhexa-2,4-dienoic acid for the ring-fission product of 2,3-dihydroxybiphenyl. It thus appears that the ring fission of the first benzene ring of biphenyl occurs between the C-1 and C-2 positions (extra-diol vicinal cleavage, in the nomenclature reported by Nozaki et al.: 1970). A similar cleavage was also demonstrated for phenylpropionic acid by Dagley et al. (1965), for 3-methylcatechol by Catelani et al. (1968), for 4-methylcatechol by Canonica et al. (1966) and for 3-phenylpentane by Baggi et al. (1972).

The isolation and identification of benzoic acid and the evidence for the formation of either 4-hydroxy-2oxovaleric acid or 2-hydroxypenta-2,4-dienoic acid, together with the results obtained from manometric experiments with cell-free extracts, allow us to correlate the degradative pathway of 2-hydroxy-6-oxo-6- phenylhexa-2,4-dienoate to that of muconic semialdehydes (Dagley et al., 1964).

From these results and those previously obtained (Catelani et al., 1971) a pathway for biphenyl metabolism by Ps. putida may be proposed (Scheme 1). This pathway seems to be different from that reported by Lunt \& Evans (1970) in this case the formation of phenylpyruvic acid accounts for a meta-cleavage of the first aromatic ring of biphenyl between the C-3 and C-4 positions (extra-diol distal cleavage).

This work was supported by the Italian Research Council (C.N.R.). We thank Dr. T. Salvatori for assistance with mass spectra.

\section{References}

Baggi, G., Catelani, D., Galli, E. \& Treccani, V. (1972) Biochem. J. 126, 1091-1097

Bruce, J. M. \& Sutcliffe, F. K. (1955) J. Chem. Soc. London 4435-4440

Canonniça, L., Fiecchi, A., Gạlli-Kienle, M., Scala, A. \& Treccani, V. (1966) Gazz. Chim. Ital. 96, 915-921

Catelani, D., Fiecchi, A. \& Galli, E. (1968) Experientig 24, 113

Catelani, D., Mosselmans, G., Nienhaus, J., Sorlini, C. \& Treccani, V. (1970) Experientia 26, 922-923

Catelani, D., Sorlini, C. \& Treccani, V. (1971) Experientia 27, 1173-1174

Dagley, S., Chapman, P. J., Gibson, D. T. \& Wood, J. M. (1964) Nature 202, 775-778

Dagley, S., Chapman, P. J. \& Gibson, D. T. (1965) Biochem. J. 97, 643-649

Dakin, H. D. (1909) Amer. Chem. J. 42, 477-498

Lunt, D. \& Evans, W. C. (1970) Biochem. J. 118, 54P-55P

Nozaki, M., Kotani, S., Ono, K. \& Senoh, S. (1970) Biochim. Biophys. Acta 22p, 213-223

Tausson, W. O. (1927) Planta 4, 214-256

Vogel, A. I. (1970) Practical Organic Chemistry, 3rd edn., p. 330, Longman Group Ltd., London

Warburg, O. \& Christian, W. (1941) Biochem. Z. 310, 384-421 